\title{
Effect of Paclobutrazol on Flowering Characteristics and Leaf Chlorophyll Content of Pineapple [Ananas comosus (L.) Merr.] cv. Mauritius
}

\author{
V.S.S.V. Prasanna*, N. Bhowmick, Aditi Chakraborty and M.K. Debnath
}

Uttar Banga Krishi Viswavidyalaya, Coochbehar, Pundibari, West Bengal - 736165, India

*Corresponding author

\section{A B S T R A C T}

\begin{tabular}{|l|}
\hline K e y w o r d s \\
$\begin{array}{l}\text { Pineapple, Paclobutrazol, } \\
\text { Growth regulator, } \\
\text { Gibberellin, Red heart } \\
\text { stage }\end{array}$ \\
\hline Article Info \\
\hline $\begin{array}{l}\text { Accepted: } \\
\text { 15 October } 2018 \\
\text { Available Online: } \\
\text { 10 November } 2018\end{array}$ \\
\hline
\end{tabular}

Pineapple [Ananas comosus (L.) Merr.] is one of the most important commercial fruit crops of the family Bromeliaceae in the world. In pineapple, irregular flowering behaviour is observed and sometimes even after 18 months of planting less than $50 \%$ of flowering occurs and unnecessary delay may be observed. Paclobutrazol (PBZ), a triazole plant growth regulator which inhibits gibberellin biosynthesis has been effectively used to induce and manipulate flowering, fruiting in several perennial fruit crops. To evaluate effect of paclobutrazol on flowering characteristics of Pineapple cv. Mauritius, the present experiment was conducted in instructional farm of Pomology and Post-harvest Technology, UBKV, Pundibari during 2016-2018. Paclobutrazol (PBZ) concentrations ranging from $100 \mathrm{ppm}$ to $300 \mathrm{ppm}$ were used in seven different treatments. Paclobutrazol @ 100ppm applied 8 months after planting $\left(\mathrm{T}_{1}\right)$ resulted in the lowest number of days (55.32 days) for red heart initiation. Lowest duration to produce 50 per cent flowering was also seen in $\mathrm{T}_{1}$ (67.26 days).

\section{Introduction}

Pineapple [Ananas comosus (L.) Merr.] is one of the most important commercial fruit crops of the family Bromeliaceae in the world It is a xerophytic, succulent, herbaceous, perennial, monocotyledonous plant. Due to presence of crown at top pineapple is also called as 'King of Fruits'. In some areas, it is known as the queen of fruits due to its excellent flavour and taste (Baruwa, 2013). To overcome the problem of irregular flowering in pineapple, forcing of pineapple is commonly done with ethylene, ethylene-releasing compounds such as ethephon, and $\mathrm{CaC}_{2}$ or acetylene when the plants are of sufficient size so as to yield fruits of marketable value. Paclobutrazol (PBZ), a triazole derivative, has been effectively used to induce and manipulate flowering, fruiting and tree vigour in several perennial fruit crops. It is a triazole plant growth regulator which inhibits gibberellin biosynthesis and regulates flowering (Davis et al., 1988). Soil application of paclobutrazol has been efficacious in promoting flowering and increasing yield in many fruit crops (Kundan et al., 2015).

\section{Materials and Methods}

The experimental site was ploughed and levelled. Trenches were made at the specified spacing. Suckers of uniform size of Mauritius 
pineapple were planted in the trenches at the spacing of $30 \mathrm{~cm} \times 45 \mathrm{~cm} \times 90 \mathrm{~cm}$ in double row planting systems during last week of November 2016. The design used in the experiment was Randomised Block Design (RBD) having 3 replications and 7 treatments. Ten plants from each replication were treated with $0.434 \mathrm{ml}, 0.868 \mathrm{ml}$ and $1.302 \mathrm{ml}$ of paclobutrazol for $100 \mathrm{ppm}, 200 \mathrm{ppm}$ and $300 \mathrm{ppm}$ concentration of paclobutrazol respectively in one litre solution. For each plant $50 \mathrm{ml}$ solution is applied at the centre of the leaf rosette and the plants were tagged. Treatment details are given below:

Leaf chlorophyll content of the paclobutrazol treated plants was compared with that of leaf chlorophyll content of the control plants by following procedure from (Robert et al., 2016). Flowering characteristics like numbers of days taken for red heart initiation, number of days taken for 50 percent flowering and flowering percentage was calculated by dividing the number of plants that came to flowering to that of total number of plants.

\section{Results and Discussion}

Data for number of days required for red heart initiation was present in Table 1. Data showed that different treatments of paclobutrazol application showed significant influence on number of days for red heart initiation. Application of paclobutrazol @100ppm applied 8 months after planting $\left(\mathrm{T}_{1}\right)$ resulted in the lowest number of days (55.32 days) for red heart initiation. While, the highest number of days (100.34) required were seen in control.

Observations recorded on days taken for 50 percentage flowering are summarized in Table 2. It showed that different treatments of paclobutrazol application showed significant influence on number of days for 50percentage flowering. Among the different treatments, lowest duration to produce 50 per cent flowering was seen in $\mathrm{T}_{1}(67.26$ days $)$ followed by $\mathrm{T}_{2}$ (75.37days). Among all the treatments maximum delay to attain 50 percent flowering was observed in control (124.35 days).

The data pertaining to the flowering percentage is presented in Table 3. An examination of data shown that paclobutrazol treatments did not exert significant influence on the flowering percentage. Maximum flowering percentage was observed in control $(86.93 \%)$ followed by $\mathrm{T}_{1}(86.62 \%)$.

The data presented in Table 4 showed that paclobutrazol in different concentrations manifested their significant effect on D-leaf chlorophyll content of the leaves. Highest chlorophyll concentration was observed in $\mathrm{T}_{1}$ (1.15 $\left.\mathrm{mg}^{-1}\right)$ and lowest concentration of chlorophyll was seen in control $\left(0.84 \mathrm{mg}^{-1}\right)$. It was also noted that different paclobutrazol treatments had no significant influence on chlorophyll b content of the D-leaf.

\section{Treatment Details}

\begin{tabular}{|l|l|}
\hline Treatment & Treatment Details \\
\hline $\mathbf{T}_{\mathbf{1}}$ & Paclobutrazol @ $100 \mathrm{ppm}$ at 8Months after planting (MAP) \\
\hline $\mathbf{T}_{\mathbf{2}}$ & Paclobutrazol @ $100 \mathrm{ppm}$ at 8MAP+9MAP \\
\hline $\mathbf{T}_{\mathbf{3}}$ & Paclobutrazol @ $200 \mathrm{ppm}$ at 8MAP \\
\hline $\mathbf{T}_{\mathbf{4}}$ & Paclobutrazol @ $200 \mathrm{ppm}$ at 8MAP+9MAP \\
\hline $\mathbf{T}_{\mathbf{5}}$ & Paclobutrazol @ $300 \mathrm{ppm}$ at 8MAP \\
\hline $\mathbf{T}_{\mathbf{6}}$ & Paclobutrazol @ $300 \mathrm{ppm}$ at 8MAP+9MAP \\
\hline $\mathbf{T}_{7}$ & Control \\
\hline
\end{tabular}


Table.1 Effect of paclobutrazol on number of days for red heart initiation

\begin{tabular}{l}
\hline Treatment \\
\hline $\mathrm{T}_{1}(\mathrm{PBZ} @ 100 \mathrm{ppm}$ at $8 \mathrm{MAP})$ \\
\hline $\mathrm{T}_{2}(\mathrm{PBZ} @ 100 \mathrm{ppm}$ at 8 \&9 MAP) \\
\hline $\mathrm{T}_{3}(\mathrm{PBZ} @ 200 \mathrm{ppm}$ at $8 \mathrm{MAP})$ \\
\hline $\mathrm{T}_{4}(\mathrm{PBZ} @ 200 \mathrm{ppm}$ at 8 \&9MAP) \\
\hline $\mathrm{T}_{5}(\mathrm{PBZ} @ 300 \mathrm{ppm}$ at $8 \mathrm{MAP})$ \\
\hline $\mathrm{T}_{6}(\mathrm{PBZ} @ 300 \mathrm{ppm}$ at 8 \&9 MAP) \\
\hline $\mathrm{T}_{7}(\mathrm{Control})$ \\
\hline S.Em $( \pm)$ \\
\hline C.D, at $5 \%$ \\
\hline
\end{tabular}

\begin{tabular}{|c|}
\hline Days for Red heart initiation \\
\hline 55.32 \\
\hline 65.94 \\
68.34 \\
72.29 \\
77.43 \\
\hline 89.24 \\
\hline 100.34 \\
\hline $\mathbf{2 . 1 0}$ \\
\hline $\mathbf{6 . 4 6}$ \\
\hline
\end{tabular}

Table.2 Effect of paclobutrazol on number of days for 50 percent flowering

\begin{tabular}{|l|}
\hline Treatment \\
\hline $\mathrm{T}_{1}(\mathrm{PBZ} @ 100$ ppm at 8MAP) \\
\hline $\mathrm{T}_{2}(\mathrm{PBZ} @ 100$ ppm at 8 \&9 MAP) \\
\hline $\mathrm{T}_{3}(\mathrm{PBZ} @ 200$ ppm at 8MAP) \\
\hline $\mathrm{T}_{4}(\mathrm{PBZ} @ 200$ ppm at 8 \&9MAP) \\
\hline $\mathrm{T}_{5}(\mathrm{PBZ} @ 300$ ppm at 8MAP) \\
\hline $\mathrm{T}_{6}(\mathrm{PBZ} @ 300$ ppm at 8 \&9 MAP) \\
\hline $\mathrm{T}_{7}(\mathrm{Control})$ \\
\hline S.Em( $)$ \\
\hline C.D, at $5 \%$ \\
\hline
\end{tabular}

\begin{tabular}{|c|}
\hline $\mathbf{5 0 \%}$ flowering \\
\hline 67.26 \\
\hline 75.37 \\
\hline 80.41 \\
\hline 85.82 \\
\hline 90.69 \\
\hline 113.48 \\
\hline 124.35 \\
\hline $\mathbf{1 . 7 8}$ \\
\hline $\mathbf{5 . 5 0}$ \\
\hline
\end{tabular}

Table.3 Effect of paclobutrazolon percentage of flowering

\begin{tabular}{|c|}
\hline Treatment \\
\hline $\mathrm{T}_{1}(\mathrm{PBZ} @ 100$ ppm at 8MAP) \\
\hline $\mathrm{T}_{2}(\mathrm{PBZ} @ 100$ ppm at 8 \&9 MAP) \\
\hline $\mathrm{T}_{3}(\mathrm{PBZ} @ 200$ ppm at 8MAP) \\
\hline T4(PBZ@ 200 ppm at 8 \&9MAP) \\
\hline T5 (PBZ @ 300 ppm at 8MAP) \\
\hline $\mathrm{T}_{6}(\mathrm{PBZ} @ 300$ ppm at 8 \&9 MAP) \\
\hline $\mathrm{T}_{7}($ Control $)$ \\
\hline $\operatorname{S.Em}( \pm)$ \\
\hline C.D, at $5 \%$ \\
\hline
\end{tabular}

\begin{tabular}{|r|}
\hline Percentage of flowering \\
\hline 86.62 \\
\hline 80.98 \\
83.24 \\
\hline 70.18 \\
\hline 76.64 \\
\hline 73.41 \\
\hline 86.93 \\
\hline $\mathbf{4 . 3 0}$ \\
\hline N.S
\end{tabular}


Table.4 Effect of paclobutrazol on chlorophyll content of D-leaves

\begin{tabular}{|c|c|c|c|}
\hline Treatment & $\operatorname{chl~a~}\left(\mathrm{mg}^{-1}\right)$ & $\operatorname{chl} \mathbf{b}\left(\mathrm{mg}^{-2}\right)$ & Total chlorophyll $(\mathbf{a}+\mathbf{b})$ \\
\hline $\mathrm{T}_{1}(\mathrm{PBZ} @ 100$ ppm at 8MAP) & 0.86 & 0.29 & 1.15 \\
\hline $\mathrm{T}_{2}$ (PBZ @ $100 \mathrm{ppm}$ at 8 \&9 MAP) & 0.86 & 0.3 & 1.16 \\
\hline $\mathrm{T}_{3}$ (PBZ @ $200 \mathrm{ppm}$ at 8MAP) & 0.88 & 0.31 & 1.20 \\
\hline $\mathrm{T}_{4}$ (PBZ@ 200 ppm at 8 \&9MAP) & 0.8 & 0.32 & 1.22 \\
\hline $\mathrm{T}_{5}$ (PBZ @ 300 ppm at 8MAP) & 0.89 & 0.30 & 1.19 \\
\hline $\mathrm{T}_{6}(\mathrm{PBZ} @ 300 \mathrm{ppm}$ at 8 \&9 MAP) & 0.92 & 0.30 & 1.22 \\
\hline $\mathbf{T}_{7}$ (Control) & 0.55 & 0.29 & 0.84 \\
\hline $\operatorname{S.Em}( \pm)$ & 0.012 & 0.013 & 0.01 \\
\hline C.D, at $5 \%$ & 0.039 & N.S & 0.05 \\
\hline
\end{tabular}

Paclobutrazol, a gibberellin inhibitor, reduces vegetative Promoter level and increases florigenic promoter there by increasing FP/VP ratio which stimulates flowering shoots in weakly inductive shoots of fruit crops (Voon et al., 1991; Yeshitela et al., 2004) For flowering to occur in pineapple, high ratio of auxin and abscissic acid to the gibberellic acid is required. As paclobutrazol inhibits the gibberellic acid synthesis it may help in early flowering.

There are evidences that the effect of paclobutrazol, reducing vegetative growth, is due to the interruption of gibberellin synthesis, by inhibition of the oxidation of the kaurene to kaurenoic acid, whose translocation occurs through the xylem (Early and Martin, 1989).This mechanism of causing flower induction by paclobutrazol by inhibiting vegetative growth might be the reason for least amount of days for 50\% flowering to occur in paclobutrazol treated plants.

Research findings were in same line with (Chaney, 2005) in case of chlorophyll content who stated that application of plants with PBZ increased production of the hormone abscissic acid and the chlorophyll component phytol, both beneficial to tree growth and health and also induced morphological modifications of leaves, such as smaller stomatal pores, thicker leaves, and increased number and size of surface appendages, and increased root density that may provide improved environmental stress tolerance and disease resistance.

Paclobutrazol altered the red heart initiation stage and also decreased the time for 50\% flowering which may lead to early harvest of the fruits

\section{References}

Baruwa, O. I. 2013. Profitability and constraints of pineapple production in Osun State, Nigeria. Journal of Horticultural Research. 21(2):59-64.

Chaney, W. R. 2005. Growth retardants: A promising tool for managing urban trees. Purdue Extension document FNR252-W. Accessed on 25-1-18 at: http://www.extension.purdue.edu/extme dia/FNR/FNR-252-W.pdf

Davis, T. D., Staffens, G. L. and Sankhala, S. 1998. N. Triazole plant growth regulators. Hort. Rev. 10: 63-96.

Early, J. D., Martin, G. C. 1989. Growth regulators in fruit production. Acta Horticulturae. 239: 73-76.

Kundan, K., Singh, H. S. and Kurian, R.M. 2015. Paclobutrazol use in perennial 
fruit crops and its residual effects. Indian Journal of Agricultural Sciences. 85 (7): 863-72

Robert, A. and Sebastio, E. 2016. Morphoanatomy of leaves and yield of pineapple plant in intercropping with cassava. BioSci J 32(4): 839-840

Voon, C.H., Pitakpaivan, C. and Tan, S. J. Mango. 1991. Cropping manipulation with paclobutrazol. Acta Horticulturae. 291: 218-9.

Yeshitela, T., Robbertse, P. J. and Stassen, P, J, C. 2004. Effects of various inductive periods and chemicals on flowering and vegetative growth of 'Tommy Atkins' and 'Keitt' mango (Mangifera indica) cultivars. New Zealand Journal of Crop and Horticultural Science. 32: 209-15.

\section{How to cite this article:}

Prasanna, V.S.S.V., N. Bhowmick, Aditi Chakraborty and Debnath, M.K. 2018. Effect of Paclobutrazol on Flowering Characteristics and Leaf Chlorophyll Content of Pineapple [Ananas comosus (L.) Merr.] cv. Mauritius. Int.J.Curr.Microbiol.App.Sci. 7(11): 2125-2129. doi: https://doi.org/10.20546/ijcmas.2018.711.238 